\title{
Zimbabwe 2.0
}

\section{Af Peter Tygesen}

Ti dage der rystede Afrika: I et forsøg på at sikre egne interesser og genvinde sin legitimitet fjernede Zimbabwes herskende elite i november Robert Mugabe ved et ublodigt paladskup. Under præsident Emmerson Mnangagwa kan regeringspartiet nyopsætte 1980'ernes forestilling om Zimbabwe som et afrikansk foregangsland.

Da hærens kampvogne omringede Mugabes hus natten til onsdag den 15 . november, havde det længe været klart for hans undersåtter, at Mugabes tid var ovre.

Den 93-årige præsident havde imidlertid hersket så længe og så brutalt insisterende, at to generationer ikke havde kendt andet. Hans styre forekom uden ende, og mens landet lukkede sig om sig selv og sin sociale og økonomiske katastrofe, forekom det hensunkent i den morbide apati, Antonio Gramsci beskrev som en følge af, at det gamle er døende, og det nye ikke kan fødes.

"Selv som lig vil han vinde det næste valg", skrydede hans kone, Grace, i februar 2017 og illustrerede, at styret med $\mathrm{Mu}-$ gabe i spidsen var som Berlinmuren: Absurd, forkvaklet og ødelæggende, men urørlig.
Siden en valgsejr i 2013 havde regeringen gældsat landet i stadig voldsommere omfang og samtidig fundet en fiks måde at trykke sine egne penge til at finansiere et dramatisk overforbrug. Da jeg besøgte landet i marts 2017, var den almindelige forventning blandt borgere og økonomer, at ZANU-PF styrede direkte mod en gentagelse af katastrofen i 2008, da Zimbabwe nåede verdens højeste hyperinflation på 500 mia. pct. Man var godt på vej: Fra januar til august 2017 voksede inflationen fra 0 til 50 pct. Men det var en lige så udbredt opfattelse, at man intet kunne gøre.

"Nu venter vi bare på, at Den Gamle dør", sagde en farmer til mig, "eller at økonomien bryder sammen". Der forekom på dette tidspunkt ikke andre mulige udgange af det jerngreb, hvormed oldingen lammede landets politiske system og dermed dets $ø$ konomiske og sociale liv. Oppositionen var splittet og svag, og ZANU-PF havde for længst demonstreret, at det besad tilstrækkelig med manipulativ kraft til at bestemme, hvem der skulle vinde valget.

Det eneste uafklarede spørgsmål syntes at være, om den ene eller den anden af disse udgange ville indfinde sig, før Mugabe vandt det kommende præsidentvalg $\mathrm{i}$ august 2018. 


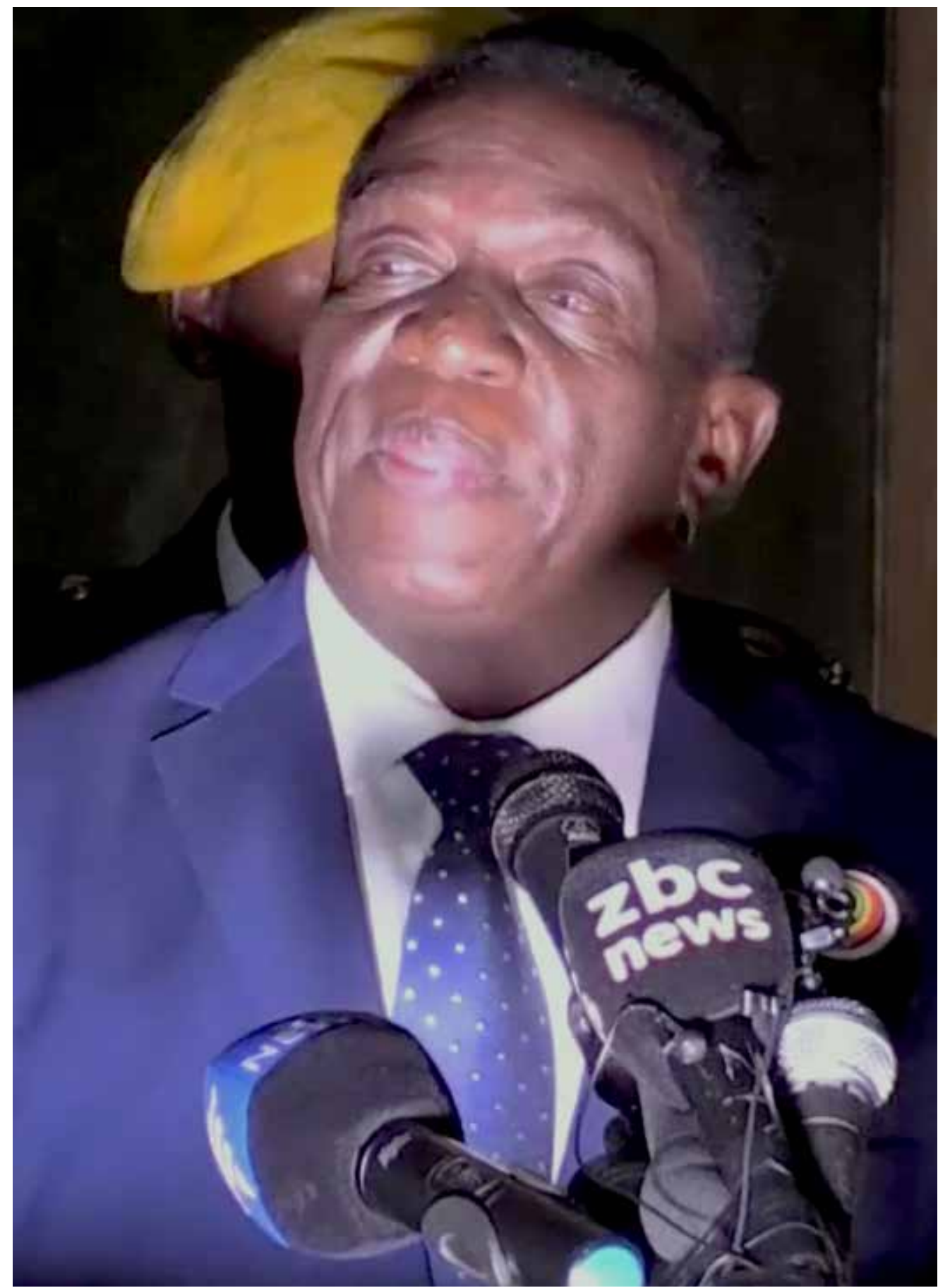

FOTO: Voice of America via wikimedia commons

Zimbabwes ny præsident Emmerson Mnangagwa i november 2017 
Så kunne han blive siddende til sit hundrede år.

\section{Brand og blod}

Kupplaner meddeles sjældent offentligheden på forhånd. Men det var netop, hvad Zimbabwes militære øverstbefalende, general Constantino Chiwenga, gjorde, da han mandag den 13 . november på en åben pressekonference sendte en klar advarsel til præsident Mugabe: "Vi bliver nødt til at minde dem, der står bag de seneste rævestreger i partiet, om, at militæret ikke vil tøve med at gribe ind, når det gælder beskyttelsen af vores revolution."

'Rævestreger' var et besynderligt ordvalg for de brutale udrensninger, der længe havde rystet regeringspartiet ZANU-PF, og som en uge tidligere fældede vicepræsident Emmerson Mnangagwa.

Partiets fløjkampe var orkestreret af $\mathrm{Mu}$ gabe selv, der i mange år mesterligt neutraliserede rivaler ved at spille dem ud mod hinanden. Han havde behændigt faet dem placeret $\mathrm{i}$ to lejre, den ene bag Mnangagwa, den anden bag Joice Mujuru, som blev anden vicepræsident i 2004.

Dette spil blev ændret dramatisk efter november 2009, da Wikileaks offentliggjorde et to år gammelt telegram fra den amerikanske ambassadør til udenrigsministeriet i Washington, hvor han beskrev et hemmeligt natligt møde med Joice Mujuru for at diskutere fjernelsen af Mugabe. Telegrammet med den dramatiske titel 'The End Is Nigh' hensatte Mugabe i paranoidisk raseri. Mujuru skulle elimineres.

Joice Mujuru var en letvægter, men det var hendes mand, Solomon, imidlertid langt fra. Som tidligere hærchef nød han stærk opbakning i hæren, og dét gjorde Joice nærmest urørlig. Ni måneder efter Wikileaks udbrød en mørk nat et inferno af en brand på Solomons farm. Brandbilen ankom uden vand. Solomon døde. Mugabe lod sig fotografere trøstende enken, mens de begge vidste, at hans næste træk ville være politisk dødeligt for hende.

Han kunne imidlertid ikke bare fjerne hende, for så ville Mnangagwa stå ene tilbage som hans arvtager. Det kunne skabe ubehagelige diskussioner om, hvornår han havde tænkt sig at gå af. Han havde for længst meddelte, at dén autoritet havde kun Gud.

For at opretholde den destruktive magtbalance mellem rivaler måtte Mugabe derfor introducere en ny kraft til neutralisering af Mnangagwa. Som redskab promoverede Mugabe en kreds af yngre, smiskende partimedlemmer, der alle var slikne efter at vippe den ældre generation af krigsveteraner af pinden. Mange var i 40-årsalderen, hvorfor gruppen blev kendt som 'G-40'.

Ingen af dem havde dog opbygget magtbaser tilstrækkeligt stærke til, at de kunne knuse Mugabes gamle fæller, og han forsynede derfor G- 40 med en brutal rambuk i form af sin yngre, ambitiøse kone, Grace. Hun var hidtil kun kendt for luksusshopping og ekspropriering af fede farme. Da hendes mand anbefalede partiet at gøre hende til leder af dets kvindeafdeling, havde det fået et tilbud, som ingen med omsorg for sit politiske eller fysiske liv kunne afslå.

Grace viste sig overmåde kapabel til både at smede rænker og beherske sprogets groveste finesser. Efter en brutal kampagne mod Joice Mujuru kulminerede hendes angreb i december 2013, da Mujuru blev fyret som vicepræsident og sammen med sine støtter udrenset af partiet, så hun, med Graces velvalgte ord, var efterladt så "ydmyget og nøgen, at ikke engang hunde vil nærme sig, fordi du stinker på trods af din parfume". 
Mugabe havde købt sig endnu nogle år på magtens tinde. I 2017 indledte han det endelige opgør med sin sidste rival. Igen var Grace rambukken: I flere offentlige taler ydmygede hun ikke bare Mnangagwa, men alle tilbageværende krigsveteraner med meddelelser om, at de ikke var noget særligt, bare fordi de havde deltaget $\mathrm{i}$ befrielsen af landet. Mugabe lod forstå, at hun skulle kåres som vicepræsident på partiets kongres i december. Som den nærmerede sig, blev først Mnangagwas støtter i partiet udrenset, og den 6. november blev han selv fyret.

\section{Revolutionens vogtere}

Resten kender vi: Bare en uge senere holdt general Chiwenga sin truende tale. Ti dage senere var Mugabe sat på historiens losseplads. Fredag den 24. november blev Mnangagwa indsat som landets nye præsident.

Begivenhederne gav genlyd over hele kontinentet. Jeg hørte nyheden på et hotel i det nordlige Uganda. Samme aften gik bølgerne højt i hotellets bar; et øldrevet skænderi blev oversat af venlige mennesker som en diskussion om, hvorvidt Ugandas hær tilsvarende kunne finde på at afsætte præsident Yoweri Museweni. Efter 31 år har han lige nu travlt med at ændre forfatningen, så han kan fortsætte. På trods af de hidsige indlæg var bargæsterne helt enige om, at nye kræfter burde træde til.

Sådan buldrede diskussioner overalt på kontinentet. Men hvor magtskiftets bølgevirkning i det øvrige Afrika kan afkodes forholdsvist let - det gav håb til de mange, der ønsker deres egne gamle hanelefanter sat på porten - er det imidlertid langt vanskeligere i Zimbabwe. Her konkurrerer mindst tre lag af parallelle fortolkningsverdener om forståelsen af perspek- tivet i Mnangagwas tiltræeden: Magtens, økonomiens og demokratiets.

Magtskiftets vigtigste resultat er foreløbig, at veteranerne i det væbnede nationalistparti ZANU-PF har konsolideret deres magt $\mathrm{i}$ håbet om at genvinde legitimitet med en ny frontfigur. To citater tjener til illustration af deres motiver. Chiwengas forgænger, general Vitalis Zvinivashi, sagde i 2002:

"Lad det være kendt at landets højeste embede er en spændetrøje, hvis bærer forventes at efterkomme frihedskampens mål. Vi vil derfor aldrig acceptere eller hverken støtte eller salutere nogen som helst med en anden dagsorden."

Det truende udsagn fra landets militære øverstbefalende var møntet på oppositionens leder, Morgan Tsvangirai, som en stor del af befolkningen på dette tidspunkt foretrak som 'bærer af landets højeste embede'.

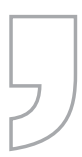
Magtskiftets vigtigste resultat er foreløbig, at veteranerne i det væbnede nationalistparti ZANU-PF har konsolideret deres magt $\mathrm{i}$ håbet om at genvinde legiti- mitet med en ny frontfigur.

Udtalelsen blev dengang fortolket som et umiskendeligt bevis for, at militæret ikke var, som krævet i forfatningen, politisk neutralt, men ene og alene ZANU-PF's væbnede gren. Den blev yderligere opfattet som en tilkendegivelse af, at militæret til enhver tid var parat til at gribe ind for at sikre partiet, styret af dets gamle garde af krigsveteraner, den fortsatte uantastede magt over landet. Derfor fik Tsvangirai aldrig lov til at vinde et valg. Det er almindelig kendt, at da han i 2008 var nærmest en sejr, sørgede hæren under 
Mnangagwas ledelse for en voldskampagne så brutal, at Tsvangirai opgav efter 400 af hans tilhængere var myrdet.

15 år efter Zvinivashis udtalelse ringede general Chiwengas meddelelse som et ekko. Nu kom truslen imidlertid ikke ude fra, men inde fra partiet: "de, som er bandsat på at kidnappe revolutionen, vil blive standset. ... Hvis drastisk handling ikke gennemføres øjeblikkeligt, er vort elskede Zimbabwe afgjort på vej til igen at blive en nykolonialistisk stat." Det var et arkaisk, besynderligt udsagn i 2017. 'Nykolonialistisk'? Hvem vil dog kolonisere Zimbabwe?

ZANU-PF's Zimbabwe har fra sin første dag haft to ansigter, to hoveder: På den ene side taler partiet revolution og lover et marxistisk, anti-imperialistisk opgør med det kapitalistiske Vestens dominans, herunder dets lokale hvide 'repræsentanter'. Retorikken danner basis for partiets påstand om social ansvarlighed som fundamentet for dets legitimitet. På den anden side følger partiet reelt en markedsøkonomisk praksis der, som tiden gik, blev stadig mere frådende rovdyrskapitalistisk.

Det tvehovede går igen i statsopbygningen. ZANU-PF fremviser et uhyre legalistisk system komplet med et tilsyneladende og ofte reelt velfungerende statsapparat, der peger i retning af en retsstat styret af konstitutionalisme og demokrati. Det har altid været magtpåliggende for ZANU-PF, at dets præsidentkandidat blev udpeget ved nationale valg velsignet af international godkendelse. Chiwenga indledte da også sin kup-advarsel med ordene: "Lad os begynde med at citere forfatningen...”.

På den anden side har partiet myrdet og fordrevet, fyret dommere og manipuleret domstole, stjålet og bedraget og i det hele taget tildelt sine ledere og tilhæn- gere straffrihed for de mest forfærdende forbrydelser, alt sammen i revolutionens navn, når det passede dem, der påberåbte sig dens opretholdelse.

\section{Økonomisk lys}

Der er en forventning i Zimbabwe om, at erfaringen fra Mugabetiden vil få ZANU-PF's nye ledelse til at føre en økonomiske politik, der leverer brød til folket som del i dens forsøg på at genvinde legitimitet.

Tro mod den tvehovede stat var Chiwengas omsorg derfor ikke alene ret-

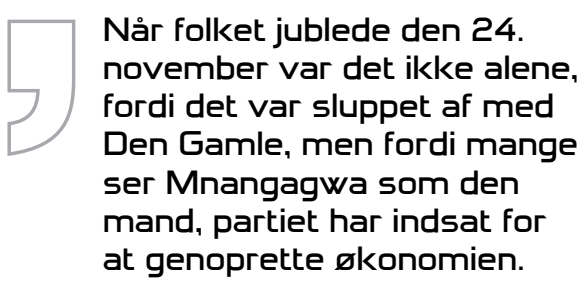

tet mod det revolutionære ansigt, men også mod det kapitalistiske. Hans analyse var præcis: "Som følge af kævleriet i ZANU-PF har der ikke været nogen udvikling af landet de seneste fem år. Den resulterende økonomiske stilstand har skabt udfordringer for den zimbabwiske befolkning som mangel på penge og stigende priser."

Når folket jublede den 24. november var det ikke alene, fordi det var sluppet af med Den Gamle, men fordi mange ser Mnangagwa som den mand, partiet har indsat for at genoprette økonomien. Han er 'erhvervsvenlig. De henviser blandt andet til det program for kommandolandbrug, han lancerede op til sidste landbrugssæson. Landmænd med adgang til kunstvanding kunne modtage gratis såsæd, kunstgødning og diesel mod til gengæld at sælge de første otte tons majs per hektar til 
det statslige opkøb (for en garanteret god pris). Resten kunne de frit sælge.

Programmet havde to overraskende sider: For det første var det lykkedes Mnangagwa at mobilisere pengene til programmet fra private investorer (tilknyttet partiet, ganske vist, og belønnet med generøse renter - men erhvervsvenligt!). For det andet tillod han diskret hvide landmænd adgang til programmet på jord, som de lejede af afrikanere. En ny klasse af effektive, hvide farmere er vokset frem, som ser fordele i tabet af ejendomsretten til jord, fordi de dermed er fritaget for investeringer i ejendomme og for forpligtelser over for de landarbejdere, der ellers skulle have løn uden for sæson samt huse, skoler, klinikker, etc.

Flere hundrede hvide farmere meldte sig til programmet sammen med, naturligvis, mange privilegerede storfarmere tilknyttet ZANU-PF. De hvides adgang til programmet var betinget af, at de holdt lav profil, for Mugabe var officielt imod. Han bøjede sig for nødvendigheden af, at landet producerede tilstrækkeligt mad frem til næste præsidentvalg. Op mod 40.000 småbønder blev også indrulleret i programmet, 'mest som vinduespynt' for præsidenten, forklarede en involveret leverandør af såsæd mig i marts 2017.

Hvorvidt programmet var en succes kan være vanskeligt at vurdere, for sjældent har Zimbabwe oplevet så perfekt en landbrugssæson som den netop afsluttede. Når lagrene bugnede af majs, skyldtes det så den rigelige regn eller kommandoprogrammet? Tilhængere hævder, at netop fordi sæsonen var så god, blev udbyttet af programmet tilsvarende ekstraordinært stort.

Allerede før han tiltrådte præsidentposten, havde Mnangagwa sikret og udvidet programmet i denne landbrugssæson. I sin tiltrædelsestale fokuserede
Mnangagwa netop på økonomien. Hans nye finansminister har lukket for pengestrømmen til de mange tabsgivende statslige virksomheder, der tidligere sugede af statskassen. Han har indsat den effektive luftmarskal Perence Shiri som landbrugsminister, angiveligt for at skabe orden i landets vigtigste økonomiske sektor og øge dens effektivitet. Siden fordrivelsen af de hvide farmere har landets matrikelsystem hængt i laser, og der foregår ingen konsekvent inddrivelse af jordskatter.

\section{Demokratisk underskud}

Mnangagwa lovede ved sin tiltræeden en 'effektiv og sikker stat'. Ikke en demokratisk. Ikke en retsstat. Men én, hvor korruptionen er mindsket, og hvor lønnen stiger.

Han har betalt for ZANU-PF's hamskifte ved at styrke militærets magt over staten. Det kan medføre styrket statslig kontrol med samfundet - på både godt og ondt. Øget respekt for loven og en effektiv jordreform vil være et gode. Men det begynder skidt: To generaler berygtede for brud på menneskerettigheder, en lang række nationale love og på folkeretten er nu ministre. Ovennævnte Shiri stod i begyndelsen af 1980'erne i spidsen for ZANU-PF's terrorkampagne mod minoritetsbefolkningen i landets sydvestlige regioner for at knuse dens opbakning til den rivaliserende befrielsesbevægelse ZAPU, hvor tusinder af civile blev myrdet og/eller tortureret. I skrivende stund (december 2017; red.) afholdes ZANU-PF's kongres med forlydender om, at Chiwenga skal kåres som vicepræsident.

"Vi har fjernet en tyran men ikke et tyranni!" tweetede menneskerettighedssagføreren og oppositionspolitikeren David Coltart den dag, folket jublede ved indsættelsen af Mnangagwa. 
Afrikas nye førerstater

Indsættelsen af Mnangagwa peger på, at ZANU-PF bevæger sig mod at skabe et land, der kan fremvise økonomisk fremgang, også for landets fattigste, men hvor et autoritært styre kan affeje enhver udfordring af dets magt. Forbilledet kunne være Kina eller Vietnam.

Som sådan vil det ligne Etiopien og Rwanda, der i vestlige medier fremhæves som de vigtigste eksempler på Afrikas økonomisk progressive lande. Begge er styret af stærkt autoritære regimer som lodrette dementier af, at demokrati skulle være en betingelse for økonomisk vækst i det fattige kontinent.

\section{Herhjemme argumentere- de Uffe Østergård i de- cember netop for, at 'vi er nødt til at slække på vores demokratiske ambitioner for Afrika'. lkke én modsagde ham offentligt.}

Zimbabwe vil kunne tage førertrøjen i denne liga af økonomisk effektive autoritære stater og dermed generobre den position, det havde i begyndelsen af 1980'erne som repræsentant for et fremadstormende Afrika.

Det råder over den vigtigste ressource for udvikling i Afrika: En veluddannet, entreprenant befolkning. Det har dygtige småbønder, erfarne storfarmere med adgang til international kapital og rester af den største industrisektor på kontinentet uden for Sydafrika. Det har jorden spækket med værdifulde mineraler som guld, platin og krom, men også diamanter og strategiske metaller. Det har kul og vand til energi - og lykkes det Mnangagwa at hele nogle af landets dybe, sociale sår, kan det hurtigt opnå en social sammenhængskraft og dynamik, som de to borgerkrigshærgede lande vil misunde. Udenlandske investorer, ifølge kilder i Zimbabwe også flere danske, har siden magtskiftet allerede vist interesse for at deltage i det forventede væksteventyr.

Om bare otte måneder står ZANU-PF under Mnangagwas ledelse over for en væsentlig prøve: For første gang i halvandet årti har det en reel mulighed for at vinde et ærligt valg. Kan partiet producere bare nogle få, mærkbare resultater, vil det kunne fastholde den nuværende bølge af medgang. Konfronteret med en svag, uorganiseret og fattig opposition, hvis dominerende parti er ledet af en kræftsvækket Tsvangirai, kunne det godt tage chancen med at opføre sig ordentligt.

Tør det - kan det overhovedet - bryde årtiers uvaner? Hvorfor skulle det? Stærke kræfter i både ind- og udland vil være tilfredse, hvis landet går økonomisk frem, og valget ser bare nogenlunde pænt $u d$. Overalt i Europa udgøres det nye sort i Afrika-politikken af muligheden for at egne virksomheder kan foretage givtige investeringer, ikke demokrati, god regeringsførelse eller respekt for menneskerettigheder. Herhjemme argumenterede Uffe Østergård i december netop for, at 'vi er nødt til at slække på vores demokratiske ambitioner for Afrika. Ikke én modsagde ham offentligt.

Vi får det første fingerpeg, når partiet skal beslutte, om det tør invitere valgobservatører fra USA, EU og Commonwealth, der de seneste årtier har været holdt ude. 